\title{
Formation of the mid-fifteenth century Kuwae caldera (Vanuatu) by an initial hydroclastic and subsequent ignimbritic eruption
}

\author{
Claude Robin ${ }^{1}$, Michel Monzier ${ }^{1}$, Jean-Philippe Eissen ${ }^{2}$ \\ ${ }^{1}$ ORSTOM, UR 1F, BP 76, Port-Vila, Vanuatu, SW Pacific, and Dept of Geology, Mines and Water Resources of Vanuatu \\ ${ }^{2}$ ORSTOM, UR 1F, BP 70, 29280, Plouzané, France
}

Received: June 29, 1993/Accepted: February 9, 1994

\begin{abstract}
In the mid-fifteenth century, one of the largest eruptions of the last 10000 years occurred in the Central New Hebrides arc, forming the Kuwae caldera $(12 \times 6 \mathrm{~km})$. This eruption followed a late maar phase in the pre-caldera edifice, responsible for a series of alternating hydromagmatic deposits and airfall lapilli layers. Tuffs related to caldera formation ( $\sim 120 \mathrm{~m}$ of deposits on a composite section from the caldera wall) were emitted during two main ignimbritic phases associated with two additional hydromagmatic episodes. The lower hydromagmatic tuffs from the precaldera maar phase are mainly basaltic andesite in composition, but clasts show compositions ranging from 48 to $60 \% \mathrm{SiO}_{2}$. The unwelded and welded ashflow deposits from the ignimbritic phases and the associated intermediate and upper hydromagmatic deposits also show a wide compositional range $\left(60-73 \% \mathrm{SiO}_{2}\right)$, but are dominantly dacitic. This broad compositional range is thought to be due to crystal fractionation. The striking evolution from one eruptive style (hydromagmatic) to the other (magmatic with emission of a large volume of ignimbrites) which occurred either over the tuff series as a whole, or at the beginning of each ignimbritic phase, is the most impressive characteristic of the caldera-forming event. This strongly suggests triggering of the main eruptive phases by magma-water interaction. A three-step model of caldera formation is presented: (1) moderate hydromagmatic (sequences HD 1-4) and magmatic (fallout deposits) activity from a central vent, probably over a period of months or years, affected an area slightly wider than the present caldera. At the end of this stage, intense seismic activity and extrusion of differentiated magma outside the caldera area occurred; (2) unhomogenized dacite was released during a hydromagmatic episode (HD 5). This was immediately followed by two major pyroclastic flows (PFD 1 and 2). The vents spread and intense magma-water interaction at the beginning of this stage decreased rapidly as magma discharge increased. Subsequent collapse of the caldera probably commenced
\end{abstract}

Correspondence to: $\mathrm{C}$. Robin in the southeastern sector of the caldera; (3) dacitic welded tuffs were emplaced during a second main phase (WFD 1-5). At the beginning of this phase, magma-water interaction continued, producing typical hydromagmatic deposits (HD 6). Caldera collapse extended to the northern part of the caldera. Previous $\mathrm{C}^{14}$ dates and records of explosive volcanism in ice from the south Pole show that the climactic phase of this event occurred in 1452 A.D.

Key words: caldera - caldera-forming event - island arc volcanism - pyroclastic flows - welded tuffs - hydromagmatism - basalts - dacites - Vanuatu

\section{Introduction}

In Central Vanuatu (Fig. 1a), a popular legend reports that Tongoa and Epi islands once formed a single large landmass, Kuwae, which was segmented during a large volcanic cataclysm preceded by strong earthquakes and tsunamis (Garanger 1972). Many people fled southward, towards Efate island, and escaped death, giving rise to the Kuwae legend.

Mitchell and Warden (1967) and Warden et al. (1972) proposed that dacitic pumice deposits that cover most of the high ground of Tongoa are probably related to this event, but they did not correlate these deposits with any caldera and Warden (1967, pp 99-100) disputed the existence of such a structure in the region. Other authors (Aubert de la Rüe 1956; Espirat 1964; Gèze 1966) postulated that this cataclysm might have been responsible for the formation of a large caldera. From bathymetric data, Carney and Macfarlane (1977) recognized an oval-shaped caldera between Epi and Tongoa islands, but these authors proposed an age of 2300 years BP for the formation of this caldera. The connection between the caldera structure and the $\mathrm{Ku}$ wae cataclysm recorded by oral folklore was not well established until Monzier et al. (1994) discussed the age of charcoal from the lower part of a thick series of 
dacitic tuffs surrounding the caldera $(\sim 120 \mathrm{~m}$ in thickness on a composite $\log$ ). New ${ }^{14} \mathrm{C}$ dates and recent marine data (Monzier et al. 1994) have defined more precisely the date of the eruption in the first half of the fifteenth century, the morphology of the submarine caldera and the volume of magma released $\left(32-39 \mathrm{~km}^{3}\right.$ DRE). These authors also discuss the possibility of two coalescent collapse structures but emphasize the likelihood that before the cataclysm, there was no caldera at this location. The present paper describes the pyroclastic deposits related to the caldera-forming event and discusses the development of the eruption which appears to have been one of the largest ever witnessed.

The caldera is located at the narrowest segment of the New Hebrides arc where a landmass, only a few kilometers wide, previously included Epi, Tongoa, Ewose and Tongariki (Fig. 1a). At this latitude $\left(16^{\circ} 50^{\prime} \mathrm{S}\right)$, the upper part of the volcanic ridge was fragmented during the cataclysm, and large sectors of this land collapsed, leaving emerged parts such as Ewose, a rocky blade-shaped island with sheer flanks.

The caldera is $12 \mathrm{~km}$ long and $6 \mathrm{~km}$ wide, with a floor $250-450 \mathrm{~m}$ below sea-level, which is divided into two distinct basins by the active Karua volcano (ap- proximately $1 \mathrm{~km}^{3}$ volume) (Fig. 1b). From seismic reflection data (Crawford et al. 1988), the thickness of tuffs infilling the depression may reach $380 \mathrm{~m}$, suggesting that the collapse may have been as much as $800-$ $1100 \mathrm{~m}$ (Monzier et al. 1994).

\section{Pre-caldera volcanism}

Pre-caldera volcanic rocks are exposed in the caldera wall along the shores of Epi and Tongoa. On Epi, shore cliffs expose a 200-m-thick monotonous sequence of subaerial origin, typically consisting of thin (1-5 $\mathrm{m}$ thick) basalt and andesite lava flows intercalated with buff or red scoria agglomerates. These agglomerates suggest a proximal vent, approximately near the center of the NW basin. Similar or thicker basaltic lava flows are exposed along the coastline of Tongoa, but on this side, they are interlayered with thicker strombolian deposits (10-30 $\mathrm{m}$ at site T1; $60 \mathrm{~m}$ at Nanisukiki Point), also suggesting a volcanic center in the east, near the present shoreline of Tongoa (Fig. 1b). Between Lupalea Point and Nanisukiki Point, a complex sequence of bedded tuffs containing vitric

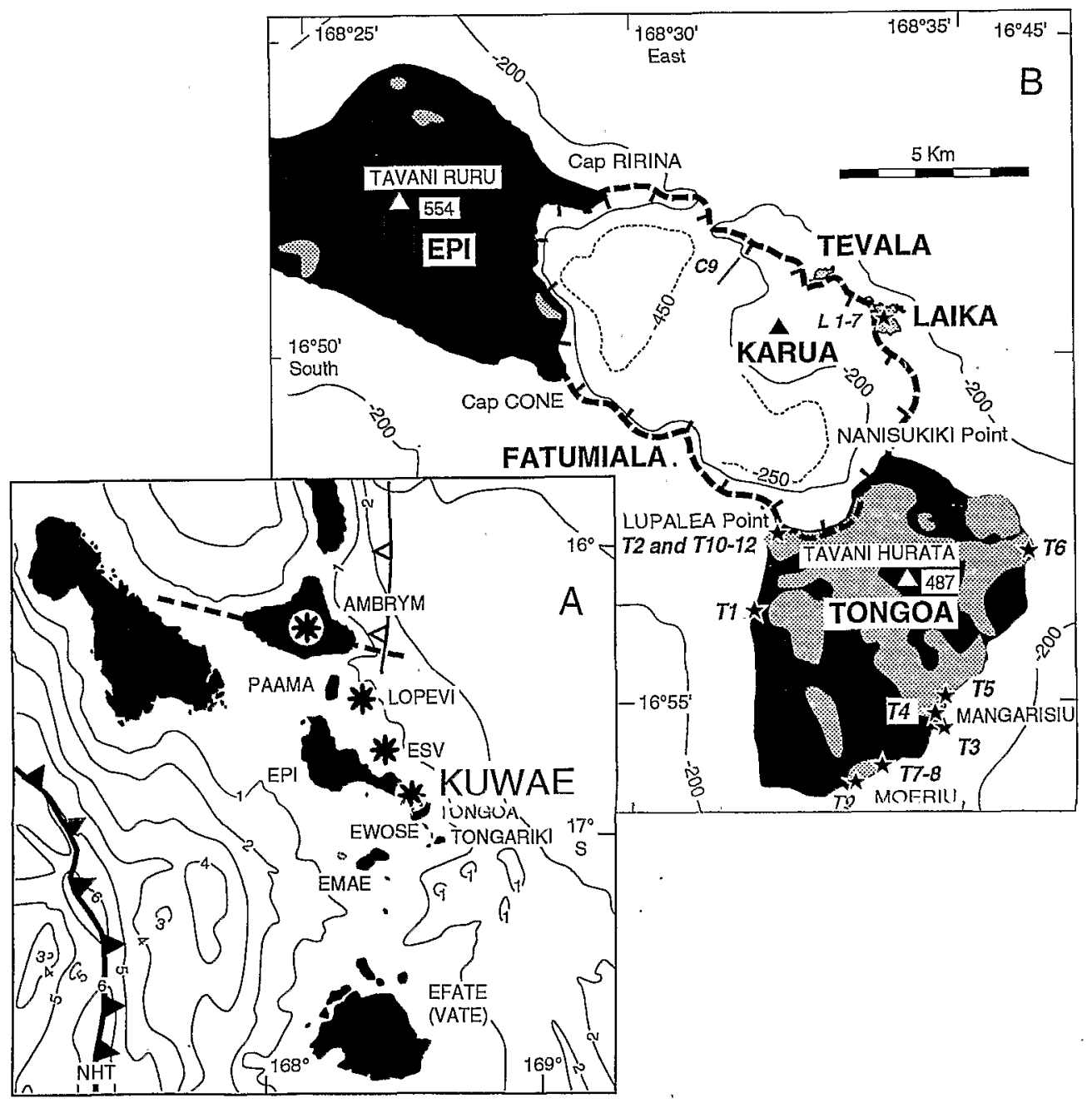

Fig. 1. a Location of Kuwae caldera in the Central Vanuatu islands. Bathymetric contour interval $=1 \mathrm{~km}$. Volcanoes with activity during the last five centuries are marked by a black star; ESV, Epi Submarine volcanoes; NHT, New Hebrides Trench; heavy line with solid triangles emphasizes the New Hebrides convergence; line with open triangles shows reverse back-arc thrusting. b Sketch diagram of the Kuwae caldera. Heavy dotted line indicates caldera margin; bold letters and numbers indicate location of sections and sites of sampling referenced in the text; stippled zones show the extent of PFD 1 and PFD 2 on Tongoa and Epi islands 
Table 1. Geochemical data. A: Whole-rock analyses; major element geochemistry in wt\% summed to $100 \%$ volatile free. ICP-ES analyses performed by J Cotten, GDR 910 "GEDO" at Brest. $\mathrm{FeO} *$, total iron as $\mathrm{FeO} ; L O I$, loss on ignition; $M g$ \# determined on the basis of $\mathrm{Fe}^{2+} /\left(\mathrm{Fe}^{2+}+\mathrm{Fe}^{3+}\right)=0.9$. Prefix in the sample number: $T$, Tongoa; $L$, Laika; see Figs. 1 b, 2 , for sample location. B: Averages and standard deviations of glass microprobe compositions (recalculated to $100 \%$ ). For comparison, the whole-rock composition of $\mathrm{C} 9 \mathrm{G}$, a dredged sample from a feeder dyke on the caldera wall (site C9, Fig. 1b) is reported

\begin{tabular}{|c|c|c|c|c|c|c|c|c|c|c|c|c|c|c|c|c|}
\hline \multicolumn{17}{|c|}{ A - Whole-rock geochemical data for Kuwae Caldera } \\
\hline \multirow{3}{*}{$\begin{array}{l}\text { Volc. unit } \\
\text { Sample }\end{array}$} & \multicolumn{3}{|c|}{ Pre-caldera } & \multicolumn{11}{|c|}{ Syn-caldera pyroclastic series } & \multirow{3}{*}{$\begin{array}{l}\text { Out. Extr. } \\
\text { lava flow } \\
\text { T6A }\end{array}$} & \multirow{3}{*}{$\begin{array}{l}\text { Karua } \\
\text { lava flow } \\
\text { C10A }\end{array}$} \\
\hline & $\mathrm{Mg} \beta$ & $\mathrm{Al} \beta$ & And. & $\mathrm{HD} 1$ & $\mathrm{HD} 5$ & HD5 & PFD1 & PFD2 & PFD2 & PFD2 & HD6 & WFD3 & WFD4 & WFD5 & & \\
\hline & T9C & $\mathrm{T} 2 \mathrm{~A}$ & $\mathrm{C} 9 \mathrm{~B}$ & $\mathrm{~T} 2 \mathrm{C}$ & $\mathrm{T} 2 \mathrm{~J}$ & $\mathrm{~T} 2 \mathrm{~K}$ & $\mathrm{~T} 4 \mathrm{~A}$ & $\mathrm{~T} 4 \mathrm{~B}$ & $\mathrm{~T} 2 \mathrm{~N}$ & L1A & L6A & L6G & L7A & L7B & & \\
\hline $\mathrm{SiO}_{2}$ & 51.60 & 52.08 & 58.74 & 51.92 & 64.33 & 62.48 & -64.43 & 63.91 & 62.49 & 64.41 & 64.51 & 64.37 & 64.40 & 64.38 & 63.88 & 53.04 \\
\hline $\mathrm{TiO}_{2}$ & 0.70 & 0.79 & 0.64 & 0.83 & 0.60 & 0.60 & 0.60 & 0.61 & 0.61 & 0.59 & 0.58 & 0.59 & 0.59 & 0.59 & 0.61 & 0.67 \\
\hline $\mathrm{Al}_{2} \mathrm{O}_{3}$ & 14.05 & 18.60 & 15.68 & 18.31 & 15.37 & 16.00 & 15.53 & 15.61 & 16.00 & 15.49 & 15.45 & 15.52 & 15.42 & 15.47 & 15.62 & 16.85 \\
\hline $\mathrm{FeO}^{*}$ & 10.17 & 9.65 & 8.27 & 10.45 & 6.35 & 6.68 & 6.25 & 6.28 & 6.69 & 6.06 & 6.08 & 6.15 & 6.16 & 6.12 & 6.48 & 10.77 \\
\hline $\mathrm{MnO}$ & 0.20 & 0.17 & 0.18 & 0.19 & 0.15 & 0.16 & 0.15 & 0.15 & 0.16 & 0.29 & 0.15 & 0.15 & 0.15 & 0.15 & 0.16 & 0.12 \\
\hline $\mathrm{MgO}$ & 8.12 & 3.96 & 3.48 & 3.87 & 1.71 & $\cdot 2.05$ & 1.68 & 1.78 & 2.05 & 1.64 & 1.66 & 1.67 & 1.66 & 1.82 & 1.73 & 5.67 \\
\hline $\mathrm{CaO}$ & 12.00 & 10.50 & 7.54 & 9.86 & 4.80 & 5.74 & 4.80 & 5.04 & 5.73 & 4.68 & 4.77 & 4.75 & 4.80 & 4.74 & 4.90 & 8.96 \\
\hline $\mathrm{Na}_{2} \mathrm{O}$ & 2.13 & 2.69 & 3.37 & 2.99 & 3.93 & 3.76 & 3.80 & 3.91 & 3.77 & 4.04 & 3.93 & 3.95 & 3.99 & 4.03 & 3.95 & 3.28 \\
\hline $\mathrm{K}_{2} \mathrm{O}$ & 0.81 & 1.29 & 1.81 & 1.28 & 2.51 & 2.29 & 2.50 & 2.47 & 2.27 & 2.57 & 2.62 & 2.60 & 2.59 & 2.46 & 2.43 & 0.48 \\
\hline $\mathrm{P}_{2} \mathrm{O}_{5}$ & 0.20 & 0.27 & 0.29 & 0.30 & 0.24 & 0.23 & 0.25 & 0.24 & 0.23 & 0.23 & 0.25 & 0.24 & 0.24 & 0.24 & 0.24 & 0.15 \\
\hline LOI $1050^{\circ} \mathrm{C}$ & -0.21 & 0.07 & -0.36 & 2.21 & 0.02 & -0.06 & 0.10 & -0.12 & -0.02 & 0.04 & -0.09 & -0.03 & 0.10 & 0.57 & -0.15 & 1.62 \\
\hline Initial total & 98.62 & 98.96 & 99.40 & 98.51 & 98.73 & 99.17 & -98.96 & 98.85 & 99.03 & 99.16 & 99.58 & 99.87 & 99.64 & 99.05 & 98.94 & 98.62 \\
\hline $\mathrm{Mg} \#$ & 0.61 & 0.45 & 0.45 & 0.42 & 0.35 & 0.38 & 0.35 & 0.36 & 0.38 & 0.35 & 0.35 & 0.35 & 0.35 & 0.37 & 0.35 & 0.51 \\
\hline \multicolumn{17}{|c|}{ B - Microprobe geochemical data for glasses from Kuwae caldera } \\
\hline \multirow{3}{*}{\multicolumn{2}{|c|}{$\begin{array}{l}\text { Samples } \\
\mathrm{SiO}_{2} \text { range }\end{array}$}} & \multirow{3}{*}{\multicolumn{2}{|c|}{$\begin{array}{l}\mathrm{HD} 2 \\
\text { T2G-T2H } \\
55.00 \text { to } 56.99\end{array}$}} & & \multirow{3}{*}{\multicolumn{2}{|c|}{$\begin{array}{l}\text { HD3 } \\
\text { T2E-T2F } \\
53.00 \text { to } 54.99\end{array}$}} & & \multirow{3}{*}{\multicolumn{2}{|c|}{$\begin{array}{l}\mathrm{HD}+\mathrm{PFD} 2 \\
\mathrm{~T} 2 \mathrm{~J}-\mathrm{T} 2 \mathrm{~K}-\mathrm{T} 4 \mathrm{~B} \\
65.00 \text { to } 68.99\end{array}$}} & & \multirow{3}{*}{\multicolumn{3}{|c|}{$\begin{array}{l}\text { HD6 }+ \text { WFD3,4,5 } \\
\text { L6A-L6G-L7F-L7B } \\
64.00 \text { to } 71.99\end{array}$}} & & \multirow{3}{*}{\multicolumn{2}{|c|}{$\begin{array}{l}\text { DYKE } \\
\text { C9G } \\
\text { WR an. }\end{array}$}} \\
\hline & & & & & & & & & & & & & & & & \\
\hline & & & & & & & & & & & & & & & & \\
\hline \multirow{2}{*}{\multicolumn{2}{|c|}{ Number of analyse }} & 46 & sd & & 34 & sd & & 39 & sd & & 104 & sd & & & \multicolumn{2}{|l|}{1} \\
\hline & & 55.86 & 1.20 & & 53.96 & 1.31 & & 66.73 & 2.09 & & 68.79 & 2.88 & & & \multicolumn{2}{|l|}{67.70} \\
\hline \multicolumn{2}{|c|}{$\mathrm{TiO}_{2}$} & 0.97 & 0.30 & & 0.90 & 0.19 & & 0.69 & 0.15 & & 0.59 & 0.02 & & & \multirow{2}{*}{\multicolumn{2}{|c|}{$\begin{array}{r}0.52 \\
14.79\end{array}$}} \\
\hline \multicolumn{2}{|l|}{$\mathrm{Al}_{2} \mathrm{O}_{3}$} & 14.93 & 1.24 & & 14.98 & 1.69 & & 14.75 & 0.10 & & 13.94 & 0.16 & & & & \\
\hline \multicolumn{2}{|l|}{$\mathrm{FeO} *$} & 10.82 & 1.87 & & 11.22 & 2.73 & & 5.72 & 1.49 & & 4.62 & 1.62 & & & \multicolumn{2}{|l|}{4.84} \\
\hline \multicolumn{2}{|l|}{$\mathrm{MnO}$} & 0.24 & 0.07 & & 0.24 & 0.05 & & 0.14 & 0.04 & & 0.08 & 0.07 & & & \multicolumn{2}{|l|}{0.12} \\
\hline \multicolumn{2}{|l|}{$\mathrm{MgO}$} & 3.83 & 0.24 & & 4.69 & 0.18 & & 1.20 & 0.20 & & 1.28 & 1.25 & & & 1.08 & \\
\hline $\mathrm{CaO}$ & & 7.97 & 0.05 & & 9.74 & 0.97 & & 3.63 & 0.40 & & 2.91 & 0.50 & & & 3.58 & \\
\hline $\mathrm{Na}_{2} \mathrm{O}$ & & 3.37 & 0.20 & & 2.74 & 0.22 & & 4.91 & 1.08 & & 4.25 & 0.23 & & & 4.23 & \\
\hline $\mathrm{K}_{2} \mathrm{O}$ & & 1.91 & $0.14^{\circ}$ & & 1.51 & 0.93 & & 2.24 & 1.06 & & 3.55 & 0.21 & & & 2.95 & \\
\hline $\mathrm{Cr}_{2} \mathrm{O}_{3}$ & & 0.10 & 0.07 & & 0.03 & 0.04 & & 0.00 & 0.00 & & 0.00 & 0.00 & & & 0.19 & \\
\hline Initial total & & 98.30 & 0.86 & & 98.39 & 0.26 & & 99.79 & 1.03 & & 99.41 & 0.77 & & & 99.77 & \\
\hline
\end{tabular}


clasts occurs below the thickest lava flow $(\sim 25 \mathrm{~m})$ in the caldera wall. This is interpreted to represent the emergent stage of a pre-caldera volcano. A petrologic study of pre-caldera formations is in progress; three analyses from these series are reported in Table 1. Additional data on Tongoa and east Epi pre-caldera rocks are available in Gorton (1974) and Roca (1978).

\section{Pyroclastic deposits}

Three composite sections illustrate the tephrostratigraphy of the whole series of tuffs surrounding the caldera and overlying the pre-caldera formations (Fig. 2). At Lupalea Point, the first section is perpendicular to the caldera wall (sites T2 and T10-12, Fig. 1b); the small island of Laika provides a good section of the upper part of the caldera wall (L1-7), and sections near Moeriu and Mangarisiu (sites T4 and T7-9) characterize the pyroclastic rocks on the SE coast of Tongoa. These tuffs are described in Table 2. In Fig. 2, a composite log of the whole pyroclastic series related to the caldera is shown.

\section{Hydromagmatic deposits (HD)}

Lower hydromagmatic sequences HD 1-4. The lower part of the Lupalea Point section exposes four composite sequences of layered deposits (HD 1-4, Figs. 2, 3 and 4a). These alternate with three sequences of airfall lapilli deposits (FL) consisting of basaltic scoriae. Commonly, these deposits consist of planar or wavy ash layers and thin cross-bedded laminae intercalated with continuous ash-and-lapilli beds. Bed thicknesses range from 2 to $80 \mathrm{~cm}$, but are typically between 20 and $30 \mathrm{~cm}$. Within a sequence, (e.g. HD 2, Fig. 4 b), beds may be concordant with contiguous layers, or may erode into underlying beds. Equant blocky vitric lapilli, small bombs, pumice and lithics are scattered in a sandy or muddy palagonitized matrix. Within the beds, zones may be enriched in lithics or alternatively in juvenile vitric clasts (hyaloclastites) or centimetersized weathered pumice. All juvenile clasts show features characteristic of water-magma interaction. The clasts are mainly blocky, glassy, and poorly vesicular (up to $40 \%$ vesicles following the classification of Houghton and Wilson 1989) with scalloped fracture surfaces, intersecting vesicles and narrow palagonitized rims. Highly vesicular glassy shards (60-70\% vesicles) also occur. In thin sections, the yellowish beds show a very fine and palagonitized matrix.

Within the whole sequence HD 1 and in places within $\mathrm{HD} 2$, deposition from surges is indicated by lack of sorting, the presence of cross bedding with well to poorly developed dunes, internal centimeter-scale layers of fine ash, internal lamination defined by contrasting grain sizes, and lenses of coarse pumice and juvenile scoria lapilli. Pale mauve or pink lenses, up to $1 \mathrm{~m}$ thick, with an indurated matrix including quenched cauliflower bombs and lithics, are also inter-

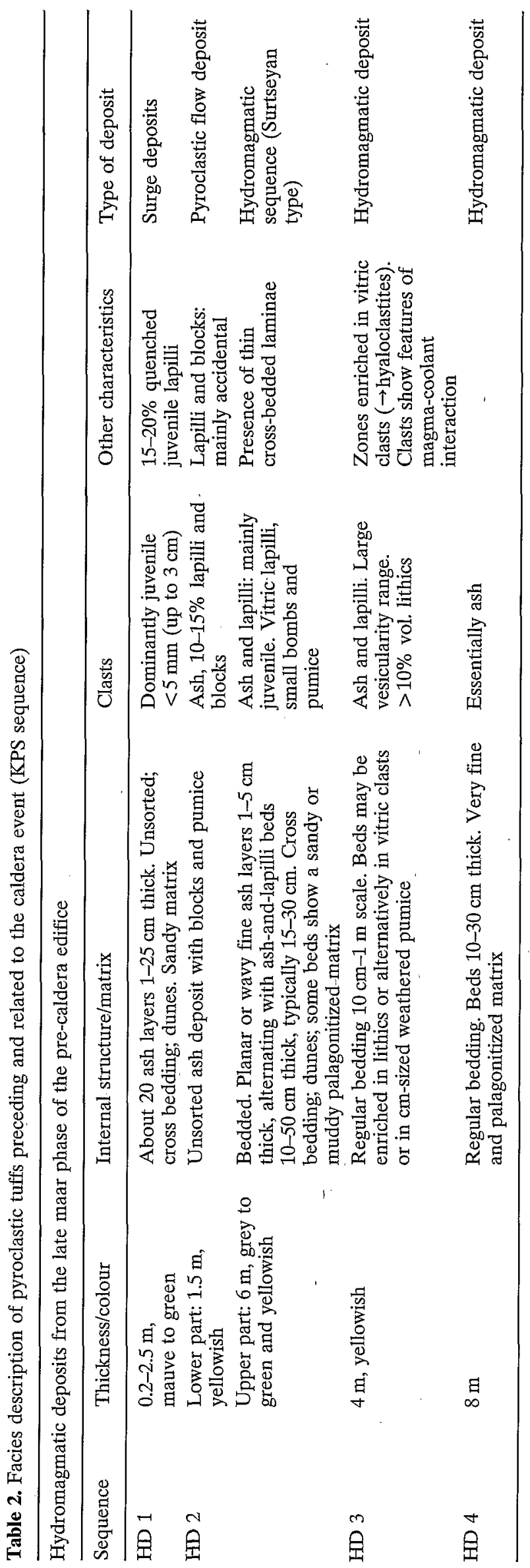


Hydromagmatic deposits (HD) and pyroclastic flow deposits (PFD) from the first main ignimbritic phase

\begin{tabular}{|c|c|c|c|c|c|}
\hline Unit & Thickness/colour & Internal structure/matrix & Clasts & Other characteristics & Type of deposit \\
\hline HD 5 & $6-7 \mathrm{~m}$, yellow & $\begin{array}{l}\text { Massive to weakly layered. Fine ash cemented } \\
\text { by fines or clayey cement. Bombs: random } \\
\text { distribution or concentration in layers. Coarse } \\
\text { ash-sized clasts altered to palagonite }\end{array}$ & $\begin{array}{l}\text { Large vesicularity range: } \\
\text { vitric clasts to pumice. } \\
\text { Abundant accidental } \\
\text { clasts (including coral } \\
\text { fragments), dm-m scale } \\
\text { bombs }\end{array}$ & $\begin{array}{l}\text { Bombs have flattened } \\
\text { shapes, breadcrust-like } \\
\text { surfaces and cauliflower } \\
\text { forms. Deposits } \\
\text { preceded by a } \\
70 \text {-cm-thick pumice fall } \\
\text { layer }\end{array}$ & $\begin{array}{l}\text { Proximal } \\
\text { hydromagmatic deposit }\end{array}$ \\
\hline $\begin{array}{l}\text { BRECCIA } \\
\text { LAYER }\end{array}$ & $5 \mathrm{~m}$ & $\begin{array}{l}\text { Heterogeneous breccia. Coarse, fines-depleted } \\
\text { matrix }\end{array}$ & $\begin{array}{l}80 \% \text { vol. accidental } \\
\text { clasts (dm-m scale) in } \\
\text { lower part. } 10 \% \text { juvenile } \\
\text { vitric blocks (up to } 1 \mathrm{~m} \text { ) }\end{array}$ & $\begin{array}{l}\text { m-sized beds or zones } \\
\text { of tuffs (from HD 1-4) } \\
\text { embayed }\end{array}$ & $\begin{array}{l}\text { Debris. } \\
\text { Co-ignimbrite breccia }\end{array}$ \\
\hline \multirow[t]{2}{*}{ PFD 1} & Lupalea: $4 \mathrm{~m}$ & Massive, unsorted, unwelded & $\begin{array}{l}\text { Ash, pumice, } 30-40 \% \\
\text { accidental blocks }\end{array}$ & & Pyroclastic flow deposit \\
\hline & $\begin{array}{l}\text { SE coast of Tongoa } \\
\text { (Mangarisiu-Moeriu): } \\
\text { up to } 10 \mathrm{~m}\end{array}$ & $\begin{array}{l}\text { Massive, unsorted, unwelded. Accidental block } \\
\text { concentration zones (up to } 80-90 \% \text { vol. lithics) } \\
\text { with juvenile glassy blocks and bombs }\end{array}$ & $\begin{array}{l}50-80 \% \text { vol. pumice } \\
(3-7 \mathrm{~cm} \text {, up to } 15 \mathrm{~cm}) \\
20-50 \% \text { lithic blocks } \\
(2-8 \mathrm{~cm} \text {, up to } 20 \mathrm{~cm})\end{array}$ & $\begin{array}{l}\text { Blocks: } 15-20 \% \text { vol. } \\
\text { Carbonized tree trunks. } \\
\text { Preceded by } 1-\text {-m-thick } \\
\text { pumice-fall deposit }\end{array}$ & \\
\hline \multirow[t]{2}{*}{ PFD 2} & Lupalea: $6 \mathrm{~m}$ & $\begin{array}{l}\text { Massive, unsorted. Unwelded ash to fine } \\
\text { lapilli-sized elements }(2-15 \mathrm{~mm})\end{array}$ & $\begin{array}{l}80-90 \% \text { vol. pumice } \\
(5-20 \mathrm{~cm}) ; \text { vitric clasts }\end{array}$ & Scarce accidental clasts & Pyroclastic flow deposit \\
\hline & Mangarisiu: $15 \mathrm{~m}$ & $\begin{array}{l}\text { Massive, unsorted to weakly layered ash, } \\
\text { unwelded }\end{array}$ & $\begin{array}{l}60-80 \% \text { vol. pumice } \\
(0.5-4 \mathrm{~cm}) \text {, up to } 25 \mathrm{~cm} . \\
10 \% \text { vitric lapilli and } \\
\text { blocks }\end{array}$ & $\begin{array}{l}\text { Scarce accidental blocks } \\
\text { ( }<5 \% \text { vol.). Densely } \\
\text { welded basal layer } \\
50 \mathrm{~cm}-2 \mathrm{~m} \text { thick. } \\
\text { Reworked by a } 6-8 \mathrm{~m} \\
\text { thick lahar }\end{array}$ & \\
\hline \multicolumn{6}{|c|}{ Hydromagmatic deposits (HD) and pyroclastic flow deposits (WFD) from the second main ignimbritic phase } \\
\hline Unit & Thickness/colour & Internal structure/matrix & Clasts & Other characteristics & Type of deposit \\
\hline HD 6 & $5 \mathrm{~m}$ & Composite sequence of 5 units (see text) & $\begin{array}{l}\text { Ash, scoria lapilli, } \\
\text { bombs, accidental clasts }\end{array}$ & $\begin{array}{l}\text { Presence of laminae. } \\
\text { Blocky and glassy clasts } \\
\text { with palagonitized rims }\end{array}$ & $\begin{array}{l}\text { Hydromagmatic } \\
\text { pyroclastic flows, surge } \\
\text { deposits }\end{array}$ \\
\hline WFD 1 & $2 \mathrm{~m}$, pink & $\begin{array}{l}\text { Homogeneous. Poorly welded very fine glassy } \\
\text { matrix }\end{array}$ & $\begin{array}{l}\text { Ash; small blocky glassy } \\
\text { clasts }\end{array}$ & & $\begin{array}{l}\text { Poorly welded ash-flow } \\
\text { deposit }\end{array}$ \\
\hline WFD 2 & $2.5 \mathrm{~m}$, pink to mauve & $\begin{array}{l}\text { Welded with fiammes and block-rich layers; } \\
\text { moderately welded }\end{array}$ & Welded ash and shards & & Welded ash-flow deposit \\
\hline WFD 3 & $7 \mathrm{~m}$, mauve & $\begin{array}{l}\text { Massive layer; banded and contorted fiammes of } \\
\text { distinct colours. Densely welded }\end{array}$ & $\begin{array}{l}\text { Welded ash and } \\
\text { collapsed pumice }\end{array}$ & & $\begin{array}{l}\text { Densely welded } \\
\text { ash-flow deposit }\end{array}$ \\
\hline $\begin{array}{l}\text { WFD } 4 \\
\text { and } \\
\text { WFD } 5\end{array}$ & $\begin{array}{l}\text { About } 20 \text { and } 30 \mathrm{~m} \\
\text { respectively, black and } \\
\text { red rocks }\end{array}$ & $\begin{array}{l}\text { Welded and brecciated; eutaxitic and } \\
\text { rheomorphic facies }\end{array}$ & $\begin{array}{l}\text { Welded ash embaying } \\
\text { vitric and eutaxitic } \\
\text { blocks }\end{array}$ & $\begin{array}{l}\text { Rheomorphic lava-like } \\
\text { facies. Autobrecciation }\end{array}$ & $\begin{array}{l}\text { Densely welded partly } \\
\text { brecciated tuff }\end{array}$ \\
\hline
\end{tabular}




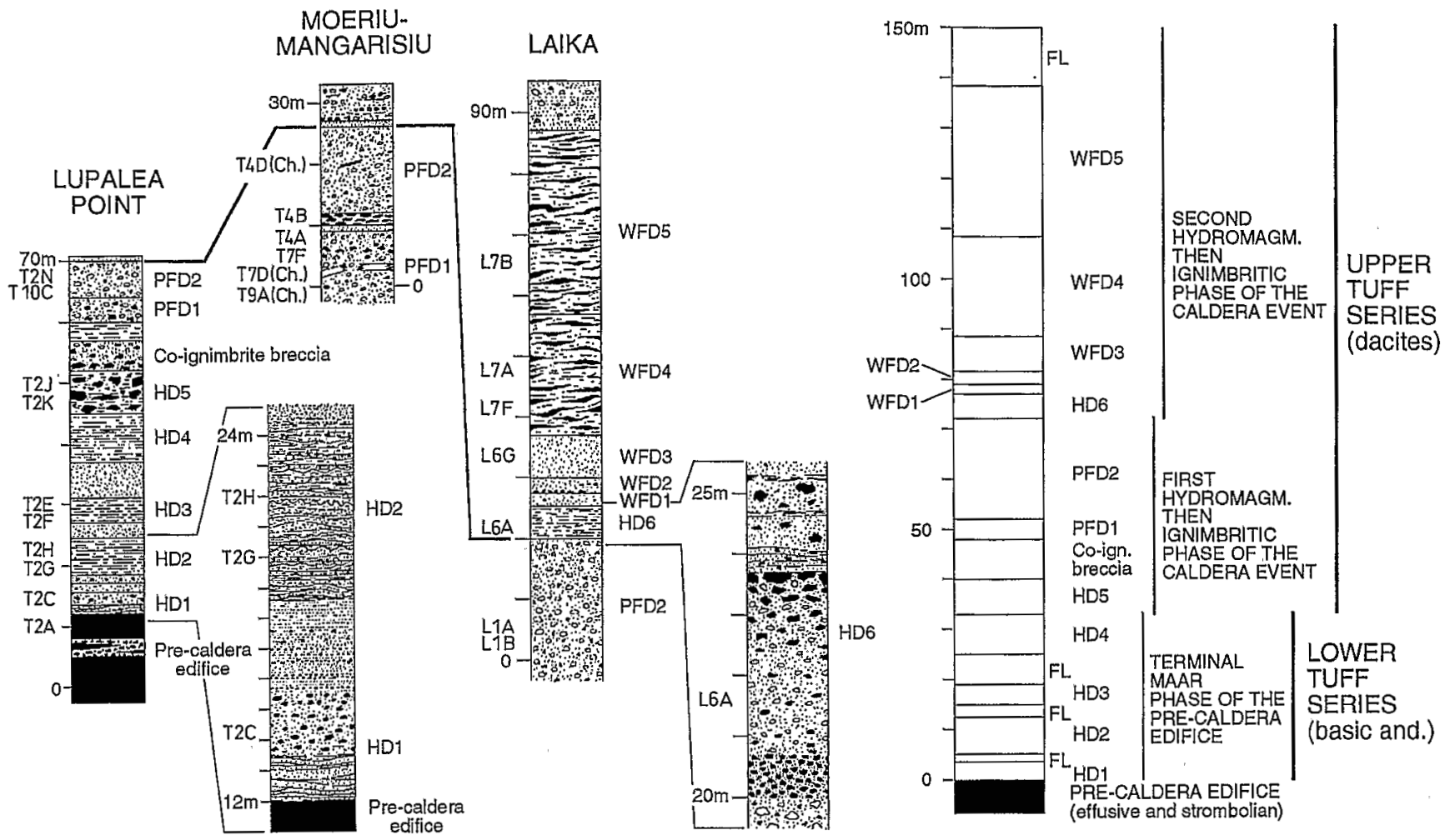

Fig. 2. Stratigraphic sections and summary log of the pyroclastic deposits surrounding the Kuwae caldera; see text and Table 2 for detailed description. $H D$, hydromagmatic deposits; $F L$, airfall lapilli deposits; $W F D$, welded pyroclastic flow deposits

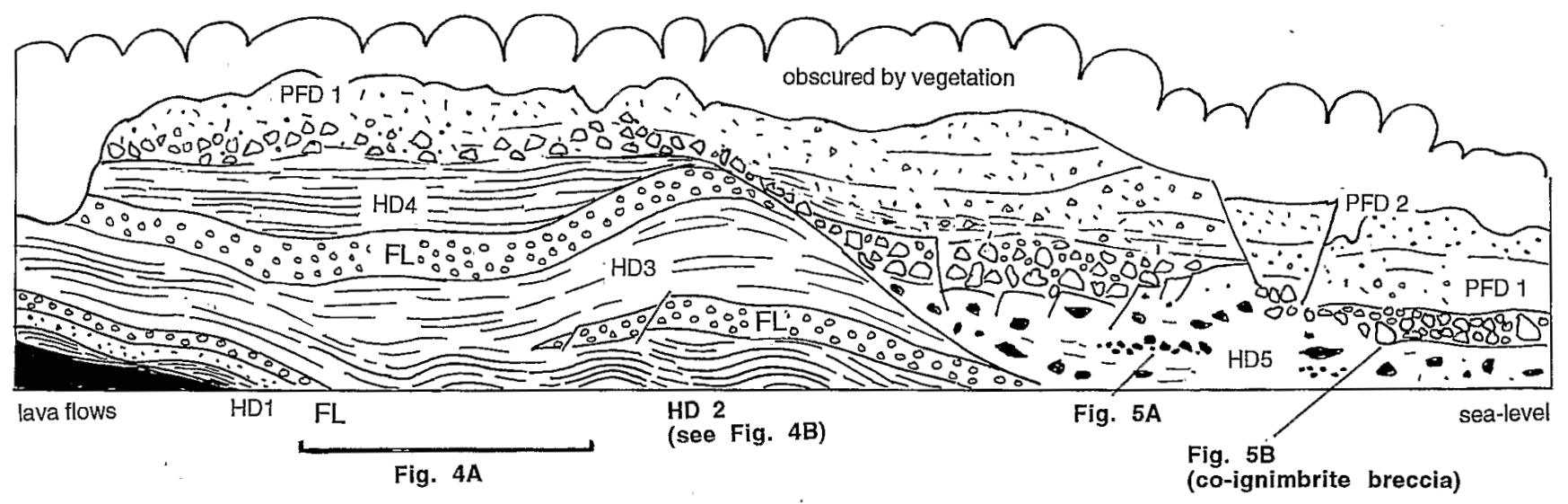

Fig. 3. Schematic diagram of the NE-SW directed Lupalea section, orthogonal to the caldera rim (the caldera wall is at the left of the figure; see location Fig. 1b). Description of hydromagmatic

calated with these surges or are found higher in sequences HD 3 and 4. In addition, ash flows also occur, such as that $1.5 \mathrm{~m}$ thick which forms the lower part of sequence HD 2 (Table 2).

Intermediate yellow tuff HD 5. This tuff is a massive to weakly layered poorly sorted breccia with an indurated matrix. Layers are defined by variations in the size of matrix clasts, or by bomb concentration layers (Fig. $5 a)$. The coarse ash-sized clasts are partly or wholly al- deposits $(H D)$, fallout lapilli deposits $(F L)$ and pumice-flow deposits $(P F D)$ in text and Table 2

tered to palagonite, and cemented by fine ash, or a clayey cement. Accidental blocks (including coral fragments) remain scarce, in contrast to abundant black, decimeter- to meter-scale juvenile vitric blocks and bombs that commonly show breadcrust-like surfaces, chilled margins, and a vesiculated core (samples T2J, $\mathrm{K}$, Table 1). The random distribution of large bombs and the lack of significant bedding suggest that this deposit has a pyroclastic origin in a near-vent setting during successive bursts of a continuous eruptive episode. 


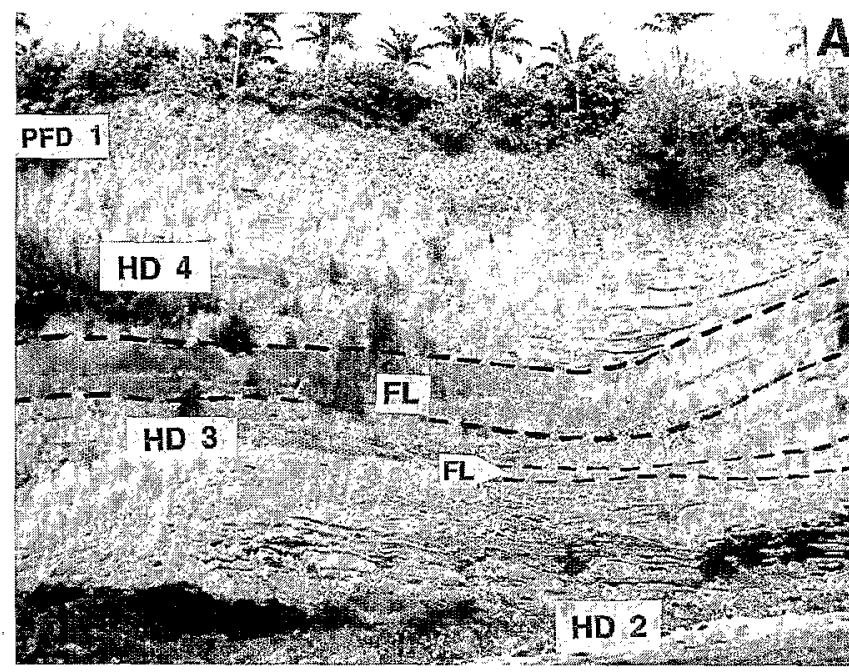

Fig. 4. A General view of hydromagmatic deposits HD 2-4 with intercalated massive beds of fallout lapilli beds $(F L)$ in the $\mathrm{Lu}-$ palea section. Refer to Figs. $1 \mathrm{~b}$ and 3 for location. Note at the top a block-rich layer corresponding to the lower part of the pumice-

Slightly vesicular juvenile clasts, breadcrust and cauliflower bombs, poor (or a complete absence of) sorting, and a sideromelane matrix, are features typical of magma-water interaction. This deposit grades upward into a co-ignimbrite breccia (see below).

Upper hydromagmatic deposits HD 6. This 5-m-thick distinctive sequence comprises: (1) a 70 -cm-thick vitric block-rich layer, with blocks up to $10 \mathrm{~cm}$ in size; (2) a pyroclastic flow deposit, containing vitric blocks (sample L6A; Table 1) in an ash-and-pumice indurated matrix; (3) surge deposits, $40 \mathrm{~cm}$ in thickness, and containing lapilli and bombs capped by (4) a 50-cm-thick indurated yellow lapilli tuff layer including bombs up to $30 \mathrm{~cm}$ in size, and (5) another similar layer of indurated yellow-to-brownish tuff with bombs, intercalated between two 10-cm-thick laminite layers. Thin sections from the brownish layers show abundant, and often banded, blocky, glassy clasts with palagonitized rims, a few vesicular lapilli and scarce lithics, enclosed in a fine, palagonitized matrix.

\section{Basaltic airfall lapilli layers}

A massive, moderately sorted fall deposit consisting of basaltic scoriae $(3 \mathrm{~cm}$ medium diameter; $15 \mathrm{~cm}$ maximum), scattered in a basaltic ash and lapilli matrix follows HD 1. This deposit grades upward into a $1.5-\mathrm{m}$ thick, coarse-grained to finer-grained, rhythmic sequence of ash and scoria layers (10-30 cm thick). Higher in the section, two additional homogeneous sequences (respectively 2.5 and $6 \mathrm{~m}$ thick; Fig. 3) of grey lapilli massive beds are intebedded with HD 2-4.

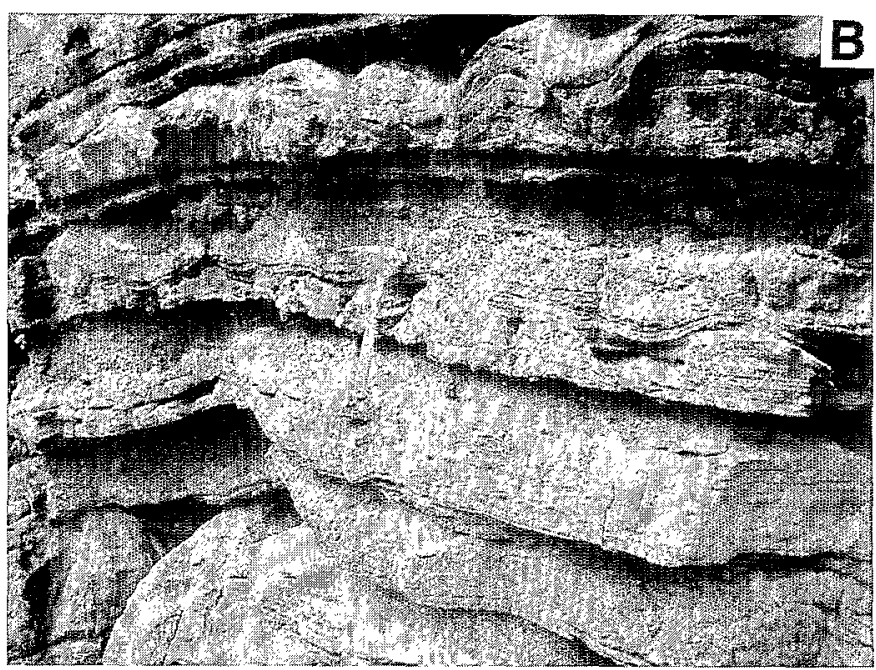

flow deposit PFD 1. B Facies representative of hydromagmatic deposits HD 2: surges and planar ash and lapilli fall beds; note the presence of drier scoria lapilli beds

\section{Co-ignimbrite breccia and unwelded pumice flow deposits (PFD 1-2)}

The upper part of the Lupalea section exposes a breccia layer which includes up to $80 \%$ blocks, in a coarse, fines-depleted, matrix (Fig. 5b). Blocks are about $10 \%$ juvenile clasts (pumiced and vitric dacitic blocks). Beds of layered tuff, some meters long, are derived from HD 1-4, and are packed into this deposit which is interpreted as the co-ignimbrite breccia from the two pyroclastic flow units (PFD 1 and PFD 2) that overlie it. The transition between the breccia and these two major pyroclastic flow deposits (samples T4A, T4B and T2N, Table 1) is progressive. The ash and pumice deposits (Fig. 5c) are characterized by dense to moderately vesicular black vitric blocks or bombs, homogeneous to the naked eye, but commonly composed microscopically of thin, banded and contorted, glassy laminations of distinct colours, and highly vesicular pumice, with apparently homogeneous glass. The lower deposit is richer in accidental blocks than the upper one.

Fig. 5A-F. Products erupted during the main ignimbritic phases related to the cladera event. A Hydromagmatic layer HD 5, showing bombs, dacitic in composition. B Co-ignimbrite breccia overlying HD 5. Blocks are mainly xenoliths, although the biggest block is a dense juvenile vitric block. C Field facies of unwelded pumice-flow deposit PFD 1 at Mangarisiu. D Contact between PFD 2 and lahars reworking the pumice deposits on the eastern coast of Tongoa. E Transition between hydromagmatic deposits HD 6 and the overlying upper sequence of welded tuffs on Laika island. F Flow laminated facies in welded tuffs WFD 5. Note the brecciated zone incorporated in the flow 

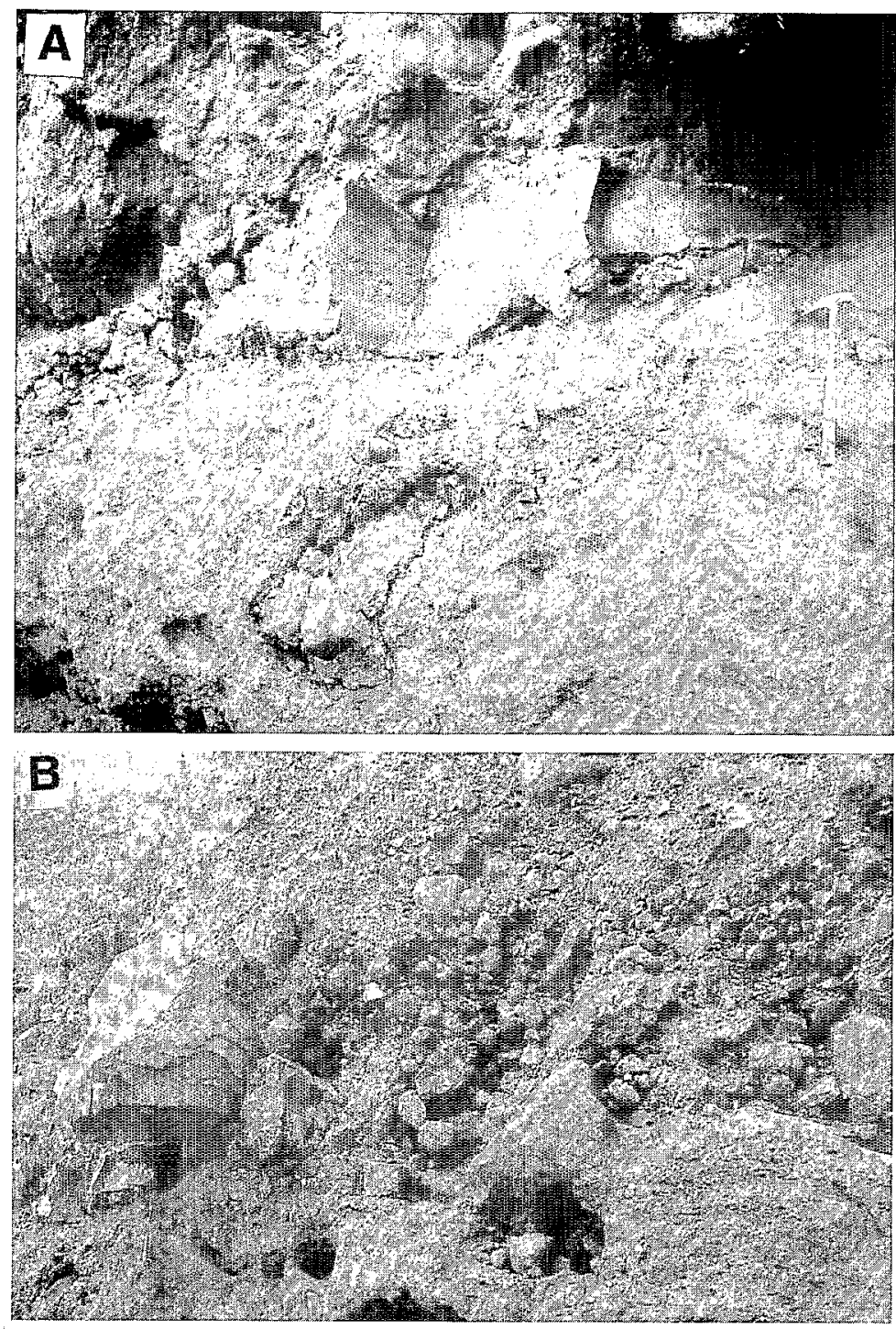

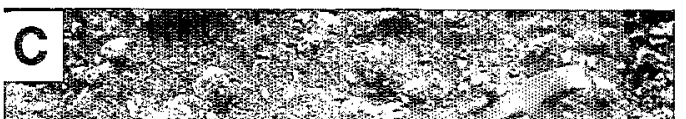

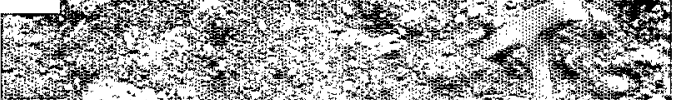
H.t.

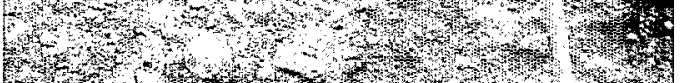

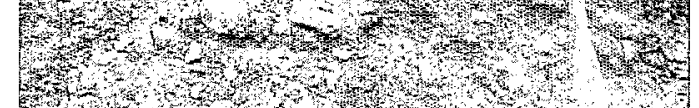

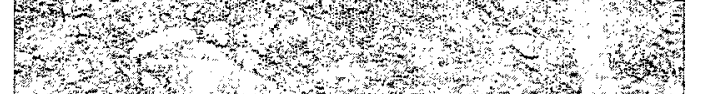

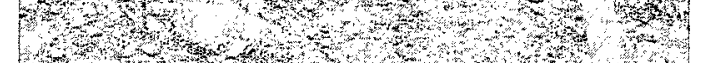
W.

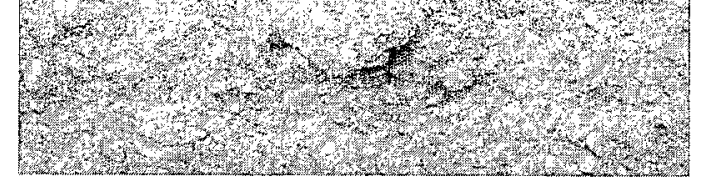
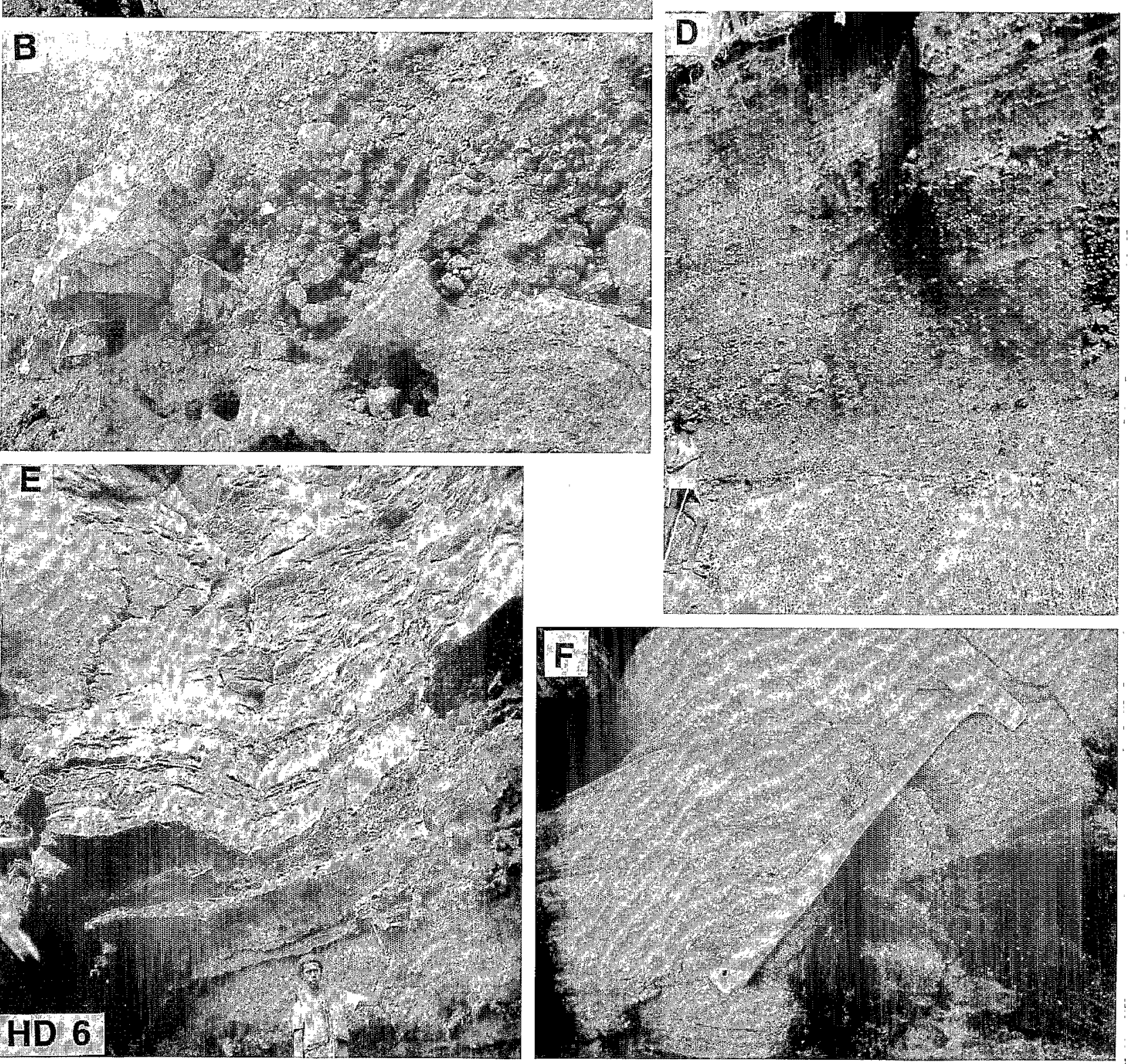
Both the PFD 1 and PFD 2 units are exposed on the SE coast of Tongoa. Near Moeriu, completely carbonized tree trunks, frequently oriented in the direction of flow (NW-SE), are common. At Mangarisiu, the upper ignimbrite unit $(15 \mathrm{~m})$ exposes a $50-\mathrm{cm}$ to 2 -m-thick densely welded basal layer (sample T4B). Here, both deposits are characterized by block concentration zones. An $80 \mathrm{~cm}-1 \mathrm{~m}$ thick co-ignimbrite ashfall layer caps the upper ignimbrite unit and along the seashore a 6-m-thick sequence of lahars reworking these pumice flow deposits is observed at the top of the section (Fig. $5 d)$.

\section{Welded flow deposits (WFD 1-5)}

Ignimbrites that become more intensely welded with height in the succession characterize the upper twothirds of the Laika section (WFD 1-WFD 5; Figs. 2, $5 e$ ). This series (Table 2) dips to the northeast and the welded tuffs can be observed along the northern side of the island where they enter the sea. They also form the main part of Tevala island. As these deposits are only observable over a small area in - or close to - the caldera wall, their detailed stratigraphy could not be determined. The thick black-and-red tuffs WFD 4 and WFD 5 that form the upper part of the section (Table 2) represent two distinct cooling units, the internal structure of which is complex and belongs to successive flow units. Rheomorphic facies are spectacular; in some places, these tuffs exhibit zones, several meters long, with flow laminations draping decimetric to metric lenses of internal breccia (Fig. 5f). In the black (lower) unit, the unambiguous vitroclastic matrix of the lower part grades upward into flow laminated tuffs and then into breccia. In the central zone, apparently continuous flow-folded laminae $1-5 \mathrm{~mm}$ thick are defined by colour, mineralogy and textural contrast. These flow laminations may disappear, leading to massive lenses $1-2 \mathrm{~m}$ thick and a few tens of meters long that-lack vitroclastic textures and closely resemble thin lava flows as described in the Bad Step Tuff by Branney et al. (1992). In general, one can note an increase in the proportion of breccia upward, the brecciated facies forming at least the upper half of the deposit. At the transition to the brecciated facies surface, the flows show large cracks with centimeter-scale chilled margins intersecting the lamination. This is evidence of high emplacement temperatures and contact with water during flowage. The large brecciated mass which forms the upper part of these tuffs is interpreted as the result of both autobrecciation and interaction between the hot flows and seawater.

\section{Dacitic airfall layers}

About $12 \mathrm{~m}$ thickness of light bedded ash-and-pumice fall deposits complete the Laika section, the total thickness of which is nearly $100 \mathrm{~m}$. These deposits mantle the island topography, with a gentle dip to the
NE, and are particularly well exposed in a small SWNE directed graben (i.e. in a radial direction) which cuts across the island. A massive basal pumice layer $2.5 \mathrm{~m}$ thick is overlain by a complex sequence of ashand-lapilli layers including surges and block-rich layers which attest to late outbursts of the caldera event.

\section{Volcanic vents}

At the southern end of Laika island, the whole vertical shore cliff $(\sim 70 \mathrm{~m})$ consists of the same welded and brecciated material as that composing WFD 4 and WFD 5. These rocks show a steeply inclined welding foliation and subvertical stretching lineation marked by undulating jointing in a direction orthogonal to the shoreline (i.e. radial to the caldera; Fig. 1b). Here, this laminar shearing and the general vertical structure of the apron are evidence for a vent occupied by large feeder dykes. On the cliff, planar surfaces, some several meters in size, with fault streaks and dipping 70 $75^{\circ}$ towards the caldera center, suggest intersection of these dykes by the caldera collapse. On the other side of the caldera, a vertical lineation along Fatumiala rock and the elongate shape of the islet in a SW-NE direction also suggest that the main body of this islet corresponds to a radial feeder dyke. On the eastern coast of Tongoa, at site T6 (Fig. 1b), two superimposed silica-rich and glassy lava flows erupted from volcanic centers on a fracture radial to the caldera. They produced hyaloclastites when they entered the sea and are covered by pumice fallout deposits. Their petrology (dacites, sample T6A) and the location of vents suggest that these lavas are extra caldera extrusions, just preceding the caldera event.

\section{Petrology of tuffs}

Twenty whole-rock analyses have been carried out on juvenile clasts from the tuff series, 11 of which are reported in Table 1 . In addition, 257 microprobe analyses of glassy clasts from the tuff series and ten of interstitial glass patches from the groundmass of an extrusion lava flow outside the caldera (T6A) were performed on 12 thin sections. Microprobe analyses were made using the fully automatized CAMECA SX50 microprobe at Brest (France). The peak and background counting time was $6 \mathrm{~s}$ and the filament current $15 \mathrm{nA}$.

\section{Lower tuff series (HD 1-4)}

One whole-rock composition from the basal hydromagmatic deposits HD 1 (sample T2C) is reported in Table 1. There are no whole-rock analyses for the lower deposits HD 2-3, but microprobe analyses were carried out on a population of 100 glass shards from samples T2E, T2F, T2G, T2H (Fig. 6). Chemical compositions range from $48-61 \% \mathrm{SiO}_{2} ; \mathrm{SiO}_{2}$ distribution is bimodal, with one peak at $53.9 \%$ mainly formed by 

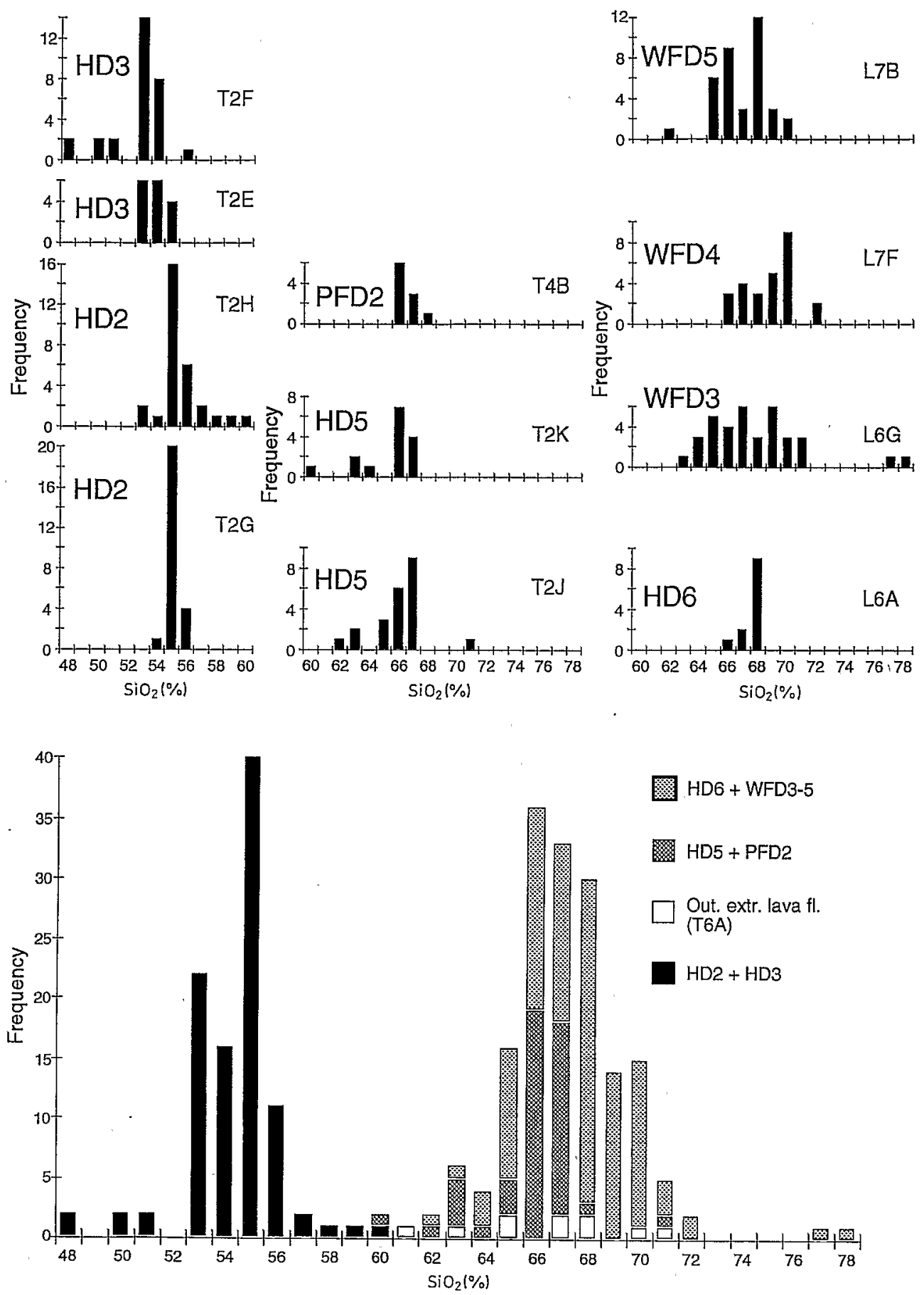

Fig. 6. Frequency histograms for $\mathrm{SiO}_{2}$ values in glasses from selected samples and from the whole tuff series. Class $48=48.00-48.99$ in $\mathrm{SiO}_{2} \%$

glasses from $\mathrm{HD} 3$, and a second at $55.8 \%$ mainly formed by glasses from $\mathrm{HD} 2$. Basic andesite compositions calculated for these two maxima (Table 1) are correlated with stratigraphic position, as the most evolved samples ( $\mathrm{T} 2 \mathrm{G}, \mathrm{H}$; depleted in $\mathrm{FeO}^{*}, \mathrm{MgO}$ and $\mathrm{CaO}$, and enriched in alkalies and $\mathrm{SiO}_{2}$ ) are from below the less evolved rocks (T2E, F). In addition, sample $\mathrm{T} 2 \mathrm{~F}$ includes a few basaltic glass fragments, whereas sample $\mathrm{T} 2 \mathrm{H}$ contains a few acid andesite vitric clasts.
Intermediate and upper hydromagmatic deposits HD 5-6 and ignimbrites

Whole-rock compositions of ignimbrites (PFD 1-2; WFD 1-5) and associated hydromagmatic deposits HD 5-6 range from acid andesites to dacites (62-66\% $\mathrm{SiO}_{2}$ ), but are mainly dacitic. Microprobe analyses were carried out on 157 microscopic glass shards or millimeter to centimeter-size fiammes from these pyroclastic rocks (samples T2J, T2K, T4B, L6A, L6G, L7B, 
L7F; Fig. 6). Taking into account the phenocryst content of these tuffs (generally 4-7\%), microprobe analyses of glasses are in good agreement, in terms of major elements, with corresponding whole-rock analyses. These analyses display two groups with a fairly welldefined unimodal distribution near 66 and $68 \% \mathrm{SiO}_{2}$. Each group corresponds to hydromagmatic deposits and their following pumice flow deposits, i.e. HD 5 + PFD 1-2 and HD 6+ WFD 1-5. An average composition has been calcualted for each group of rocks (Table 1). Vitric clasts in tuffs from Laika (i.e. the upper group) are slightly more silicic than those of Tongoa (lower group). Interestingly, interstitial glass patches from the groundmass of sample T6A display a wide compositional range from $61-71 \% \mathrm{SiO}_{2}$.

\section{Discussion}

\section{The Kuwae Pyroclastic Series (KPS): a probable} single pyroclastic series

On Tongoa, all sequences of hydromagmatic and fallout deposits from the lower tuff series, the massive hydromagmatic unit HD 5 and the co-ignimbrite breccia, occur only near the caldera along the NW coast of the island. In constrast, both the upper part of the Lupalea Point section and the whole Moeriu-Mangarisiu composite section clearly expose the same two major, unwelded, pumice-rich flow deposits PFD 1 and PFD 2 (Fig. 2). PFD 2 also forms the base of the shore cliff of Laika. Pumice-flow deposits identical to those of Moeriu-Mangarisiu on Tongoa, and including carbonized trunks, were also observed on Epi island.

The time between the eruption of early hydromagmatic deposits HD 1 and the eruption of flows PFD 12 is not known. Nevertheless, two arguments suggest that the eruption of the whole sequence of pyroclastic deposits was of short duration: (1) in spite of the tropical climate, no soils occur between any of the tuffs, and there are no inter-layered lava flows; the pre-caldera lower deposits HD 1 mark the transition to a new phase (maar phase in Fig. 2) with eruptive styles drastically different from the previous ones (lavas and strombolian deposits); (2) the stratigraphic position of the co-ignimbrite breccia shows that conduits allowing upward movement of the dacitic magma opened before the end of the hydromagmatic phase. This phase (and intervening magmatic episodes) may have lasted months or even years. Thus, we propose that the KPS forms a coherent volcanic series, first emitted during a long-lasting hydromagmatic phase, and then during a large ignimbritic event which caused the caldera collapse. Thick hydromagmatic products preceding (HD 1-4) - or at the base of the dacitic tuffs (HD 5 and 6) - are a notable characteristic of the Kuwae caldera, in contrast to other calderas of similar size that originated in major, essentially dry Plinian eruptions.
Eruptive styles during the late volcanic stage of the pre-caldera edifice

Processes relevant to magma-water interactions in sub-aqueous and emergent basaltic volcanism are reviewed by Kokelaar (1986). Interelationships between the water/magma ratio and the resulting products and styles of volcanism have been established (Sheridan and Wohletz 1983; Wohletz 1986; Wohletz and McQueen 1984). During the course of an eruption, variations in the water/magma ratio leads to a change in eruptive style. The initial surges forming HD 1 probably resulted from the collapse of tall and massive jets (ultra surtseyan, Kokelaar 1986) corresponding to a low mass ratio $\left(\mathrm{H}_{2} \mathrm{O} /\right.$ magma $)$ when the maar phase was initiated. The remainder of the products from the maar phase (bedded tuffs with minor surges HD 2-4) formed during less powerful activity. These products, together with the intercalated airfall deposits, show that $\mathrm{H}_{2} \mathrm{O}$ /magma mass ratios were variable. Each eruption consisted of ash-producing, wet eruptions (HD) followed by drier, magmatic eruptions, with the closing stage characterized by rapid magma rise, opening of the vent and depletion of water. This phenomenon was repeated three times during the maar phase.

\section{Transition phase from low-energy volcanism to high-energy volcanism; role of magma-water interaction}

As a whole, the lower sequence of deposits shows increasing hydromagmatism with time. This evolution led to the emission of thick hydromagmatic deposits HD 4 and then HD 5 at the start of the cataclysmic event, when a change in the composition of the products occurred. In layer HD 5 and in the following lag breccia ignimbrites, abundant large-sized lithics and chilled bombs indicate high-energy hydromagmatism. Although large juvenile clasts are blocky in shape and sparsely to moderately vesicular, i.e. typical of those from hydromagmatic processes, these deposits also contain a large proportion of vesiculated juvenile lapilli, heralding the emission of the ensuing pumice-rich pyroclastic flows. They reflect the transition from small-volume activity to large-volume activity, with widening of vents and collapse of a large eruptive column that originated in a dacitic magma conduit.

Lithic ash-fall layers produced by hydromagmatic to vulcanian or plinian activity together with surge deposits and lithic block-falls are common in the formation of large craters such as Coseguina (Self et al. 1989), and in medium-sized calderas such as Tambora caldera (Sigurdsson and Carey 1989). During the Minoan eruption at Santorini, after the initial Plinian column, magma-water interaction is marked by the emission of pyroclastic surges in phase 2 and then cool, poorly fluidized pyroclastic flows of phase 3 (Sparks and Wilson 1990). At Kuwae, the presence of hydromagmatic deposits preceding the ignimbrites strongly suggests triggering of the Plinian eruption by magma-water in- 
teraction, as has also been interpreted for the ignimbrite sequences of Tanna, elsewhere in the New Hebrides arc (Eissen et al. 1992; Robin et al. 1994). A similar interpretation is proposed for the Campi Flegrei (Neapolitan yellow tuff; Orsi et al. 1992). Monzier et al. (1991) and Robin et al. (1993) also showed that magma-water interaction played a major role in the development of the eruption leading to the formation of Ambrym caldera, only $80 \mathrm{~km}$ to the NNW.

Higher in the ignimbritic sequence, the hydromagmatic episode HD 6 demonstrates that water-magma interactions still took place between the two major ignimbritic phases. Nevertheless, the upper part of the KPS is dominated by dry magmatism, resulting from high discharge from fissures along crosscutting caldera faults. Taking into account the vertical variation in facies from PFD 1 to WFD 5, all facies from extremely low-grade to extremely high-grade ignimbrites are represented on the caldera edge. Deposits grade vertically from non-welded (low grade) PFD 1-2 ignimbrites (Walker 1983) to lava-like ignimbrites (Ekren et al. 1984; Branney et al. 1992) in WFD 4-5, with intermediate poorly welded facies (WFD 1), non-rheomorphic welded facies (Ross and Smith 1961; Ragan and Sheridan 1972) and rheomorphic facies (Schmincke and Swanson 1967). This evolution suggests an increase in temperature during deposition as the eruption developed, probably related to decreasing magma-water interaction and a consequent decline in cooling rates.

\section{Interpretation of petrologic data}

Glasses from the caldera tuff series are usually heterogeneous, showing a wide compositional range. These compositions, together with whole-rock compositions, display defined trends on oxide- $\mathrm{SiO}_{2}$ variation diagrams that can be interpreted in terms of fractional crystallization (work in progress). Glass compositions are inferred to represent liquids from a zoned magma chamber. During the eruption, these layers disintegrated and droplets of various compositions were mechanically mixed, but generally without homogenization of the resulting product. In Table 1 , a striking similarity is evident between the averages of glass compositions and the whole-rock composition of sample $\mathrm{C} 9 \mathrm{G}$, a porphyritic dacite with fine-grained groundmass from a probable feeder dyke on the caldera wall (site C9, Fig. 1b). Similar compositional variations in dacitic or rhyolitic ignimbrites have been reported already in the literature (Schmincke 1976; Gardeweg and Rasmirez 1987; Wright and Walker 1981). Larger compositional ranges are rare: for example, compositions from basalt to rhyolite characterize the composite flow P1 from Gran Canaria (Freundt and Schmincke 1992). The Kuwae ignimbrites are also remarkable as their compositions grade into the mafic compositions observed in the hydromagmatic products that immediately precede them. At Tanna, ignimbrite compositions ranging from basic andesites to dacite-rhyolite (54$69 \% \mathrm{SiO}_{2}$ ) have been observed (Robin et al. 1994).

\section{Model of caldera formation}

Associations between hydromagmatic and Plinian deposits have been described in many calderas. To our knowledge, however, none of the recorded examples shows the striking evolution from one eruptive style to the other which occurred twice at Kuwae, i.e. from HD 5 to PFD 1-2 and from HD 6 to WFD 1-5. At Kuwae, magma-water interactions played an important role before the event, as well as at the beginning of each ignimbritic phase. The numerous eruptive episodes that precede the ignimbrite outpourings suggest months or even years of relatively moderate activity before the collapse paroxysm. Oral folklore suggests that earthquakes and tsunamis started before the paroxysmal phase. Possibly, this initial phase was accompanied by radial faulting allowing the ascent and extrusion of dacitic magma (sample T6A). The main ignimbritic phases were probably short, as similar eruptions (e.g. Krakatau, 1883) seem generally to have lasted for 2-3 days or less.

During the phase preceding the caldera event, external water (probably seawater) interacted with basic andesite magma. As magma of this composition would probably not be found in the upper central part of the differentiated chamber, earlier magma-water interaction probably occurred under a lateral submarine part of the volcanic field. There, basic andesite magma rose either from an intermediate level of the chamber or from a secondary magma chamber, through a fissure swarm. At this time, a volatile-charged acid cap, dacitic in average composition, was stored under the roof of a magma chamber beneath the central part of the volcanic field. The following mechanism is suggested: opening of vents related to earlier hydromagmatic eruptions weakened the rock-pile at the top of the central magma chamber, which progressively failed. This probably allowed water to reach the volatile-charged cap, as the locus of explosive activity migrated downward. At this stage, magma-water interaction resulted in the outpouring of hydrovolcanic dacitic products, as a mixture of gas, pumice and dense vitric blocks (layer HD 5). As the conduit became wider, depressurization in the differentiated cap produced expansion and eruption of slightly heterogeneous dacitic magma (ignimbrite and co-ignimbrite breccia). An increase in magma discharge may have overwhelmed the water, and the eruption became much drier. If collapse occurred at this stage, it was probably in the southern part of the caldera, accompanied by the formation of low-grade tuffs. The renewed infiltration of seawater during a volcanic lull was responsible for producing the upper hydromagmatic sequence HD 6 and probably, for triggering the second Plinian phase (high grade WFD 1-5 on Laika island).

Thus, the unfolding of the late stages of activity leading to the Kuwae caldera collapse may be summarized as follows:

1. Moderate hydromagmatic and magmatic (fallout deposits) activity from a central vent during a long-lasting eruption. The products have mafic compositions and 
affect an area slightly wider than the present caldera. At the end of this stage, initial seismo-tectonic activity occurred together with early extrusions of differentiated magma outside the caldera area (both events being possibly related to regional doming?).

2. Unhomogenized dacite released during a first main Plinian phase (two major pumice flows), with the resulting products devastating a wide area; intense magma-water interaction at the beginning of this phase decreased rapidly. Collapse probably started in the SE part of the caldera, as suggested by faults which affected layer HD 5 and were covered by the overlying deposits (Fig. 3).

3. Unhomogenized dacite - slightly more silicic than the early products - released during a second main eruptive phase, leading to thick units of welded tuffs. At the beginning of this phase, magma-water interaction was still intense enough to produce typical hydromagmatic deposits. This phase ended with the main collapse.

\section{Age of the caldera event}

On the basis of $\mathrm{C}^{14}$ datings, Monzier et al. (1994) proposed an age in the first half of the fifteenth century with a best fitting for all data near 1425 A.D.

As suggested by the large extent of the dacitic pumice-fall deposits (up to Tongariki island to the south and to central Epi to the north) and by the volume of ejected materials (32-39 $\mathrm{km}^{3}$ DRE), this eruption probably injected huge amounts of silicate microparticles and acid gases into the stratosphere and had an indirect impact on a global scale. A few anomalies of mean acidity within annual layers in the Greenland ice core occur at 1411,1417 , and from 1452 to $1460 \mathrm{AD}$ ( \pm 1 year) (Hammer et al. 1980). One of these anormalies may have been caused by the Kuwae eruption. Delmas et al. (1992) have shown that the major excess of sulfate and choride concentrations around 1450 A.D. (mean peak in 1452 A.D.) in ice cores from Antarctic is related to a cataclysmic volcanic event from the south hemisphere. Thus, we postulate that the Kuwae event began in 1450 A.D. and experienced its climactic phase in 1452 A.D:

Acknowledgements. This work was financially supported by ORSTOM UR 1F, directed by J Recy, and the French Foreign Affairs Ministry (MAE). We thank D Charley (ORSTOM, Vanuati) for useful participation during fieldwork, $M$ Bohn for his help in performing the microprobe analyses and J Cotten for the ICPES analyses. We are also very grateful to to anonymous reviewers and to Mike Hawkins for constructive and helpful comments and improvement of the English translation. C Mortimer and S Temakon past and present directors of the Department of Geology, Mines and Water Resources of Vanuatu, constantly supported our investigations.

\section{References}

Aubert de la Rüe E (1956) La géologie des Nouvelles-Hébrides. Volcanisme. J Soc des Océanistes 12:89-93
Branney MJ, Kokelaar P (1992) A reappraisal of ignimbrite emplacement: progressive aggradation and changes from particulate to non particulate flow during emplacement of high-grade ignimbrite. Bull Volcanol 54:504-520

Branney MJ, Kokelaar P, Mcconnel BJ (1992) The Bad Step Tuff: a lava-like rheomorphic ignimbrite in a calc-alkaline piecemeal caldera, English Lake District Bull Volcanol 54:187199

Carney JN, Macfarlane A (1977) Submarine geology, Epi-Tongoa. In: Macfarlane A (ed) Annual report of the Geological Survey for the year 1975. New Hebrides Geol Surv, Port Vila pp 11-13

Crawford AJ, Green HG, Exon NF (1988) Geology, petrology and geochemistry of submarine volcanoes around Epi island, New Hebrides island arc. In: Greene HG, Wong FL (eds) Geology and offshore resources of Pacific island arcs - Vanuatu region. Circum-Pacific Council for Energy and Mineral Resources Earth Science Series, 8, Houston, Texas, 301-327

Delmas RJ, Kirchner S, Palais JM, Petit JR (1992) 1000 years of explosive volcanism recorded at the South Pole. Tellus 44-B, 335-350

Eissen J-P, Robin C, Monzier M (1992) Découverte et interprétation d'ignimbrites basiques à Tanna (Vanuatu). (With English version). CR Acad Sc Paris, 315-2:1253-1260

Ekren EB, McIntyre DH, Bennet EH (1984) High-temperature, large volume, lavalike ash-flow tuffs without calderas in southwestern Idaho. US Geol Surv Prof Pap 1272:1-76

Espirat J-J (1964) Etude géologique de l'île Tongariki et observations sur la géologie des îles Shepherd. Rapport du Bureau des Recherches Géologiques et Minières, Nouméa, p 41

Freund A, Schmincke H-U (1992) Mixing of rhyolite, trachyte and basalt magma erupted from a vertically and laterally zoned reservoir, composite flow P1, Gran Canaria. Contrib Min Petrol 112:1-19

Garanger J (1972) Archéologie des Nouvelles Hébrides. ORSTOM, Publications de la Société des Océanistes, Musée de l'Homme, Paris, 30, 405 pp

Gardeweg M, Ramirez CF (1987) La Pacana caldera and the Atana Ignimbrite. A major ash-flow and resurgent complex in the Andes of northern Chile. Bull Volcanol 49:547-566

Gèze B (1966) Sur l'âge des derniers cataclysmes volcanotectoniques dans la région centrale de l'arc des Nouvelles-Hébrides. Bull Soc Géol France (7), VIII:329-333

Gorton MP (1974) The geochemistry and geochronology of the New Hebrides. PhD Thesis, Australian National University, Australia, $300 \mathrm{pp}$

Hammer CU, Clausen HB, Dansgaard W (1980) Greenland ice sheet evidence of postglacial volcanism and its climatic impact. Nature 288:230-235

Houghton BF, Wilson CJN (1989) A vesicularity index for pyroclastic deposits. Bull Volcanol 51:451-462

Kokelaar P (1986) Magma-water interactions in subaqueous and emergent basaltic volcanism. Bull Volcanol 48:275-289

Mitchell AHG, Warden AJ (1967) Geology of Tongoa. In: The geology of the Central Islands. New Hebrides Geol Surv, report 5, Port Vila:38-46

Monzier M, Robin C, Eissen J-P, Picard C (1991) Découverte d'un large anneau de tufs basaltiques associé à la formation de la caldera d'Ambrym (Vanuatu, SW Pacifique). C R Acad Sci Paris, 313, Série 2:1319-1326

Monzier M, Robin C, Eissen J-P (1994) Kuwae ( 1425 AD): the forgotten caldera. J Volcanol Geotherm Res 59:207-218

Orsi G, D'Antonio M, De Vita S, Gallo G (1992) The Neapolitan Yellow Tuff, a large-magnitude trachytic phreatoplinian eruption: eruptive dynamics, magma withdrawal and caldera collapse. J Volcanol Geotherm Res 53:275-288

Ragan DH, Sheridan MF (1972) Compaction of the Bishop tuff, California. Geol Soc Am Bull 83:95-106

Robin C, Eissen J-P, Monzier M (1993) Giant tuff cone and $12 \mathrm{~km}$-wide associated caldera at Ambrym volcano (Vanuatu, New Hebrides Arc). J Volcanol Geotherm Res 55:225-238 
Robin C, Eissen J-P, Monzier M (1994) Ignimbrites of basaltic andesite and andesite compositions from Tanna, New Hebrides Arc. Bull Volcanol (in press)

Roca J-L (1978) Contribution à l'étude pétrologique et structurale des Nouvelles-Hébrides, Thèse Doctorat 3ème Cycle, Université des Sciences et Techniques du Languedoc, Montpellier, $157 \mathrm{pp}$

Ross CS, Smith RL (1961) Ash-flow tuffs, their origin, geological relations and identification. US Geol Surv Prof Pap 366:177

Schmincke H-U (1976) Geology of the Canary islands. In: Kunkel G (ed) Biogeography and ecology in the Canary Islands. W Junk, The Hague: 67-184

Schmincke H-U, Swanson DA (1967) Laminar viscous flowage structures in ash-flow tuffs from Gran Canaria, Canary Islands. J Geol 75:641-644

Self S, Rampino MR, Carr MJ (1989) A reappraisal of the 1835 eruption of Cosigüina and its atmospheric impact. Bull Volcanol 52:57-65

Sheridan MF, Wohletz KH (1983) Hydrovolcanism: basic considerations and review. J Volcanol Geotherm Res 17:1-29

Sigurdsson H, Carey S (1989) Plinian and co-ignimbrite tephra fall from the 1815 eruption of Tambora volcanol. Bull Volcanol 51:243-270

Sparks RSJ, Wilson CJN (1990) The Minoan deposits: A review of their characteristics and interpretation. In: Hardy D (ed) Thera and the Aegean world III, Vol 2. Thera Foundation, London, pp 89-99

Walker GPL (1983) Ignimbrite types and ignimbrite problems. J Volcanol Geotherm Res 17:65-88

Warden AJ (1967) The geology of the Central Islands, New Hebrides Geol Surv, report 5, Port Vila. 108 pp

Warden AJ, Curtis R, Mitchell AHG, Espirat J-J (1972) Geology of the Central Islands. 1: 100000 New Hebrides Geol Surv Sheet 8, Port Vila

Wohletz KH (1986) Explosive magma-water interactions: thermodynamics, explosion mechanisms, and field studies. Bull Volcanol 48:245-264

Wohletz KH, McQueen RG (1984) Experimental studies of hydromagmatic volcanism. In: Explosive volcanism: Inception, evolution and hazards. Studies in Geophysics, National Academy Press, Washington DC, pp 158-169

Wright JV, Walker GPL (1981) Eruption, transport and deposition of ignimbrite: a case study from Mexico. J Volcanol Geotherm Res 9:111-131 